\title{
INVESTIGATING DAIRY FARMERS' RESILIENCE UNDER A TRANSFORMING POLICY AND A MARKET REGIME: THE CASE OF NORTH KARELIA, FINLAND
}

\author{
FuLvio Rizzo \\ Department of Geographical and Historical Studies, University of Eastern Finland, Joensuu
}

Manuscript received: December 22, 2016

Revised version: March 7, 2017

Rizzo F., 2017. Investigating dairy farmers' resilience under a transforming policy and a market regime: The case of North Karelia, Finland. Quaestiones Geographicae 36(2), Bogucki Wydawnictwo Naukowe, Poznań, pp. 85-93, 1 table, 7 figs.

\begin{abstract}
AвSTRACT: The European dairy sector is currently facing unprecedented challenges under a transforming policy and a market regime. The expected changes will have relevant consequences for land use, the landscape, and the environment in rural areas dominated by dairy farming. Within this context, the aim of this paper is twofold. First, key characteristics of milk production in the region of North Karelia will be illustrated. Secondly, some light will be shed on dairy farmers' challenges and adaptations to the dairy sector's structural changes, and to what extent they contribute to the resilience of agricultural systems. In the light of an evident milk crisis, the findings suggest that farmers' key challenge is the profitability of running a dairy enterprise. One of the consequences of the poor economic situation is the pressure to make investments in the conditions of a constantly changing policy. Flexibility and the ability to understand future trends are fundamental in adapting to socio-economic changes and unpredictability. Adaptation to unpredictability would not be possible without a key characteristic of farming activity: agriculture is not only a source of an income, but also a way of life, a sense of belonging to the land that significantly affects farmers' decision-making.
\end{abstract}

KEY WORDS: milk production, resilience, farmers' adaptations, farmers' challenges

Fulvio Rizzo, Department of Geographical and Historical Studies, University of Eastern Finland, Tulliportinkatu 1, Educabuilding, P.O. Box 111, FI-80101 Joensuu, Finland; e-mail: fulvio.rizzo@uef.fi

\section{Introduction}

The structure of farming is constantly evolving, and the visible adjustments are often a result of changes in the conditions faced by farmers (Evans 2009). Among such changes, one key condition is policy-making: "the development of agrifood policy is a continuously changing area, in particular with respect to increased globalisation of the food supply" (Frewer et al. 2011: 1514-1515). Structural changes in the European dairy sector are currently a timely topic of discussion among policy makers, the media, and the academic world (Zimmermann, Heckelei 2012). Along with a review of the Common Agricultural Policy (CAP) for the period 2014-2020, recent market changes and specific policy revisions concerning the dairy sector affect the terms of its production (McDonald et al. 2014). The European Union (EU) dairy prices have dropped significantly in the light of two major events: first, the announcement of the Russian embargo in 2014, and secondly, the end of milk quotas in 2015, whose goal was to introduce a free-market environment for milk production across Europe (European Parliamentary Research Service 2015). 
The CAP introduced milk quotas in 1984 to restrict milk oversupply; such a system provided national quotas at the Member State level, and an individual quota fixed for each producer or purchaser, with a levy (the 'super-levy') payable by those who exceeded their quotas (European Parliamentary Research Service 2015). In April 2015, the EU milk quota system was abolished, both in response to an increasing global demand for milk and agreements on trade liberalisation in global dairy markets (EU 2015). Small farmers, farmers in mountain areas or those with higher production costs are very likely going to suffer without the protection of the quota system (Groeneveld et al. 2016).

In this context, the aim of this paper is twofold. First, key characteristics of milk production in the region of North Karelia, Finland, will be illustrated. Within the Finnish context, North Karelia is characterised by a strong food sector and a traditional food culture. From an economic point of view, milk production is clearly the most important production sector with two thirds of farming revenues coming from milk (Yle 2014). At the same time, the short summer leads to a long indoor period; it is for this reason that requirements for infrastructure are high, causing large costs of production. Secondly, some light will be shed on dairy farmers' challenges and adaptations to the sector's structural changes, and to what extent they contribute to the resilience of agricultural systems. The main assumption is that farmers, in their management decisions, do not necessarily follow the logic of mainstream economics typical of most approaches to agro-industrial production (Farmar-Bowers, Lane 2009 in Darnhofer 2010).

As in McDonald et al. (2014), the main aim here is to understand the interplay between the revised terms of dairy production and farmers' decision-making, and how such an interplay may enable a system to cope with surprise. Since farmers are key actors in agricultural systems, their adaptations and strategies increasingly appear to be very important in any approach to promote transition towards more sustainable farming, including its technological, cultural, institutional, and normative reconfiguration (Darnhofer et al. 2010; Feola, Binder 2010). It is thus necessary to understand how the on-going change of agricultural systems is reflected both within the farm itself and in relation to farmers' decision-making (Darnhofer et al. 2010).

The paper is structured as follows. Section two offers the theoretical background necessary to enrich the analysis of the data. Section three describes the data collection and the methodology used. Section four illustrates the key characteristics of milk production in the study region, North Karelia. Section five introduces dairy farmers' challenges in the light of the current changes, and deals with their adaptations and strategies. Section six discusses final conclusions.

\section{Theoretical background}

By envisaging agriculture as a socio-cultural rather than a mechanistic profit-making endeavour (Spencer, Stewart 1973: 531; Evans et al. 2002: 313), a simple focus on market competitiveness and efficiency is not enough to ensure a long-term survival of farms (Darnhofer 2010). In this light, the paper uses the concept of resilience to carry out data analysis. Resilience is the "capacity of a system to absorb disturbance and reorganize while undergoing change so as to still retain essentially the same function, structure, identity, and feedbacks" (Walker et al. 2004: 2). Resilience thinking may underlie strategic farm management, and at the same time may contribute to a better understanding of the interlinkages and the challenges involved in moving towards sustainable food production, diverse agro-ecosystems, and lively rural areas (Darnhofer 2010). Its starting point is the complexity of social-ecological systems, as well as their unpredictable development (Walker et al. 2004).

Traditionally, the different approaches to farm resilience focus either on material structures or on the agency of farmers and other social groups. The approach focusing on material structures emphasises ecological as well as social dynamics. As for ecological dynamics, it takes into account the material structures of farms (for example, their size, type, diversity of activities, production practices, resource endowment), and how they affect ecosystems. The social dynamics approach, in turn, considers markets, policies, labour availability, and how 
they affect production practices (Darnhofer et al. 2016).

The farmers' agency approach pays attention to farmers' perceptions and how their choices influence the adaptation of their farms. Kings and Ilbery (2010) argue that decision-makers operating in an environment base their decisions on the environment as they perceive it, not as it is. Farmers are not passive recipients of transformative forces; in contrast, they are active agents in the process of change by generating activities and creating market opportunities. This is due to a variety of factors, including tight interlinkages between the family and the farm (labour, living and working space), social norms (e.g. ensuring that the farm is passed on to the next generation, reciprocal neighbourly help), and belief structures (local knowledge, risk aversion). Burton (2004: 208) in this regard claims that "the farm is not simply an object, it is consubstantial with the farmer, and, important$l y$, it is the very part of the farmer that is used to express his/her family's identities, both to other members of the farming community and to the world in general". Positioning actors at the centre of the investigation allows an analysis of the diversity of practices within similar structures (including topography, policies, markets, farm size), and how farmers' value matter (Van der Ploeg 1994).

Like Darnhofer et al. (2016), this paper adopts a relational approach to resilience, which bridges and integrates the conceptual distinction between structure and agency on the one hand, and the social and the ecological on the other. In a relational perspective, farmers are not separated from the spatial and temporal contexts in which they are embedded; as a result, resilience is placed within the never stable tangible and intangible relations that constitute farming. Since a relational approach emphasises how farming modifies and is modified by relations between a range of natural and social processes, it contributes to overcoming the division between nature and culture (Darnhofer et al. 2016). As a matter of fact, the land has always been the place of many agricultural practices, of many and diversified systems of cultivation linked to the characteristics of the soil, the climate, the environment, the community, and traditions (Magnaghi 2010).

\section{Data collection and methodology}

The region selected for the investigation, North Karelia, is located in Eastern Finland (Fig. 1). The fieldwork started by interviewing three key experts from the local dairy and farming sector: one representative of $\mathrm{MTK}^{1}$, one from Pro Agria $^{2}$, and one from the largest dairy cooperative in the region, ItäMaito ${ }^{3}$. The goal of those first-stage interviews was to gather information on the state and trends of the milk sector in North Karelia (such as the dairy farming structure, policy and market changes, the financial situation of milk farms), and to gather dairy farmers' contact information. In the second stage, 17 face-to-face semi-structured interviews with dairy farmers were conducted. Through the means of data triangulation, they were complemented and reinforced by an on-line survey sent via webropol by the ItäMaito Cooperative to their 415 farmers producing in North Karelia, a total of 31 farmers answering the questionnaire.

As for the qualitative data, the dairy farmers' contact information was drawn from an Excel database provided by MTK. It was not complete, since it included 369 farmers (out of the total of 554 in 2015). Furthermore, it did not contain updated information either on the type of dairy production (conventional, organic, shifting to organic), or on the farmers' current status (some of them had changed production or left agriculture

MTK stands for Maajametsätaloustuottajain Keskusliitto (Central Union of Agricultural Producers and Forest Owners), and it is the Finnish-speaking interest organisation for farmers (about $90 \%$ of Finnish farmers belong to some interest organisation, including both the Finnish, and the Swedish-speaking groups; the latter has its own interest organisation, Svenska lantbruksproducenternas centralförbund).

2 Pro Agria is an advisory organisation for farm development. Expertise for instance focuses on farm investments, business and financial managements, R\&D, production, and the environment (Pro Agria 2014).

3 The ItäMaito Cooperative was established in early 2010 by the merging of dairy cooperatives Alueosuuskunta Promilk, Kainuun Osuusmeijeri, Liperin Osuusmeijeri, Nurmeksen Osuusmeijeri and Osuuskunta Idän Maito. The ItäMaito cooperative which is owned by dairy farmers - produces about $25 \%$ of Finland's milk. Milk collected by ItäMaito is sold to Valio Oy for processing. About $27 \%$ of Valio Oy is owned by the ItäMaito Cooperative. This cooperative aims to promote the development of some 1,970 milk farms in Eastern Finland. 


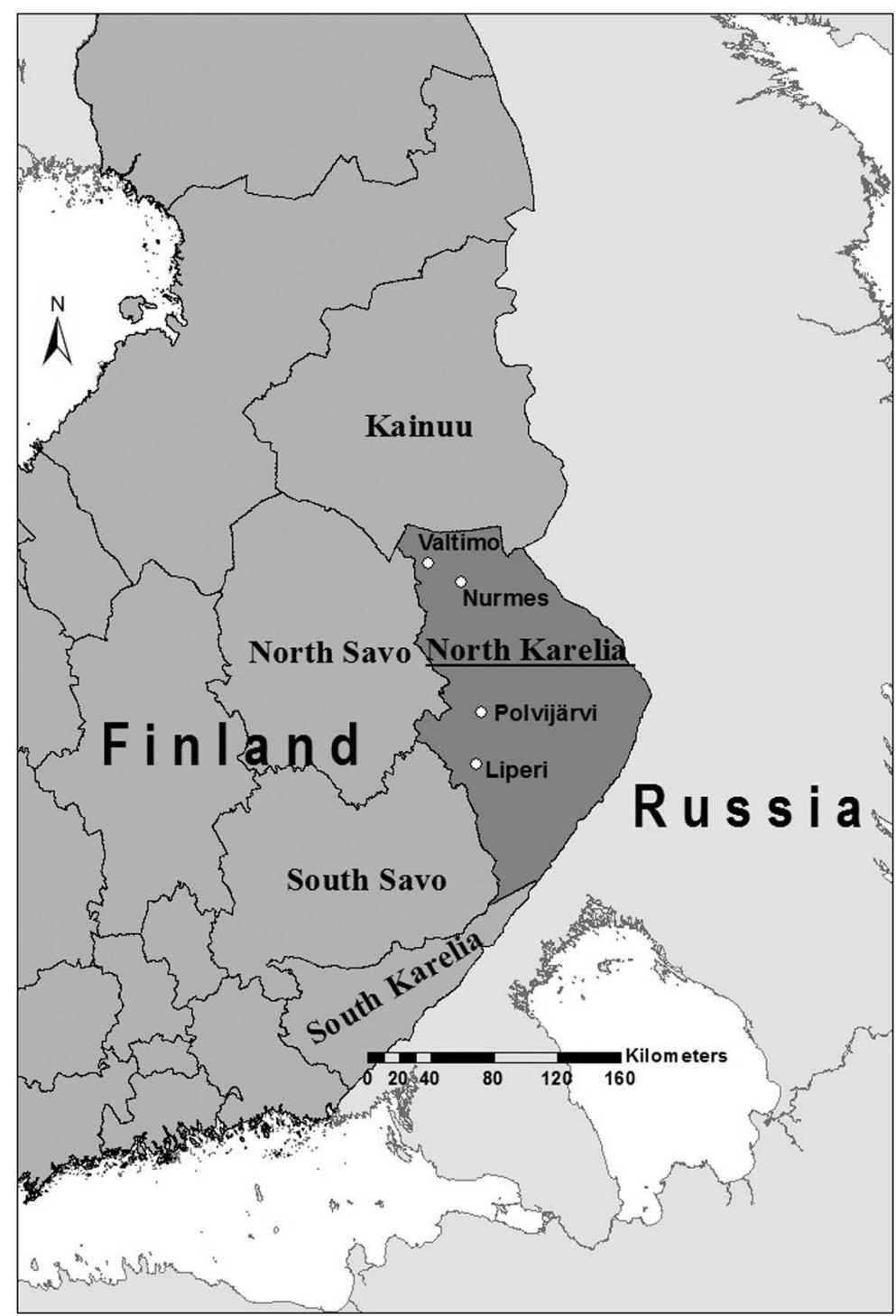

Fig. 1. Location of North Karelia in Finland and municipalities where the research was conducted.

altogether). This was a first indication of the development of this sector which will continue to be in a restructuring phase for years. Information may change significantly from one year to another.

The interviews were collected in the municipalities of Liperi $(\mathrm{n}=9)$, Polvijärvi $(\mathrm{n}=2)$, Nurmes $(\mathrm{n}=3)$ and Valtimo $(\mathrm{n}=3$; Fig. 1$)$. While most of the interviewees were chosen randomly from the database, a few, particularly the organic farmers, were suggested by the interviewees. Organic farmers in the region of North Karelia are very few (about 20 at the time of data collection), so this was the only way to contact them. Among the farmers interviewed, three were organic, and two had changed production (one to crops, the other to meat production).
Both the semi-structured interviews and the survey included qualitative and quantitative data subdivided into four main sections. The first included farmers' personal information (such as age, gender, education, side income, participation in civil society). The second section dealt with farms' structure and functioning (such as the number of hectares, type of production and ownership, challenges in running the farm). The third section covered farmers' future plans and strategies, such as concrete and potential investments on the farm. Last but not least, the fourth section concerned farmers' perception of agriculture (including factors influencing resilience, work and place satisfaction, societal attitudes to agriculture). Since the data were recently collected at the time of the writing (end of November 2016), the 


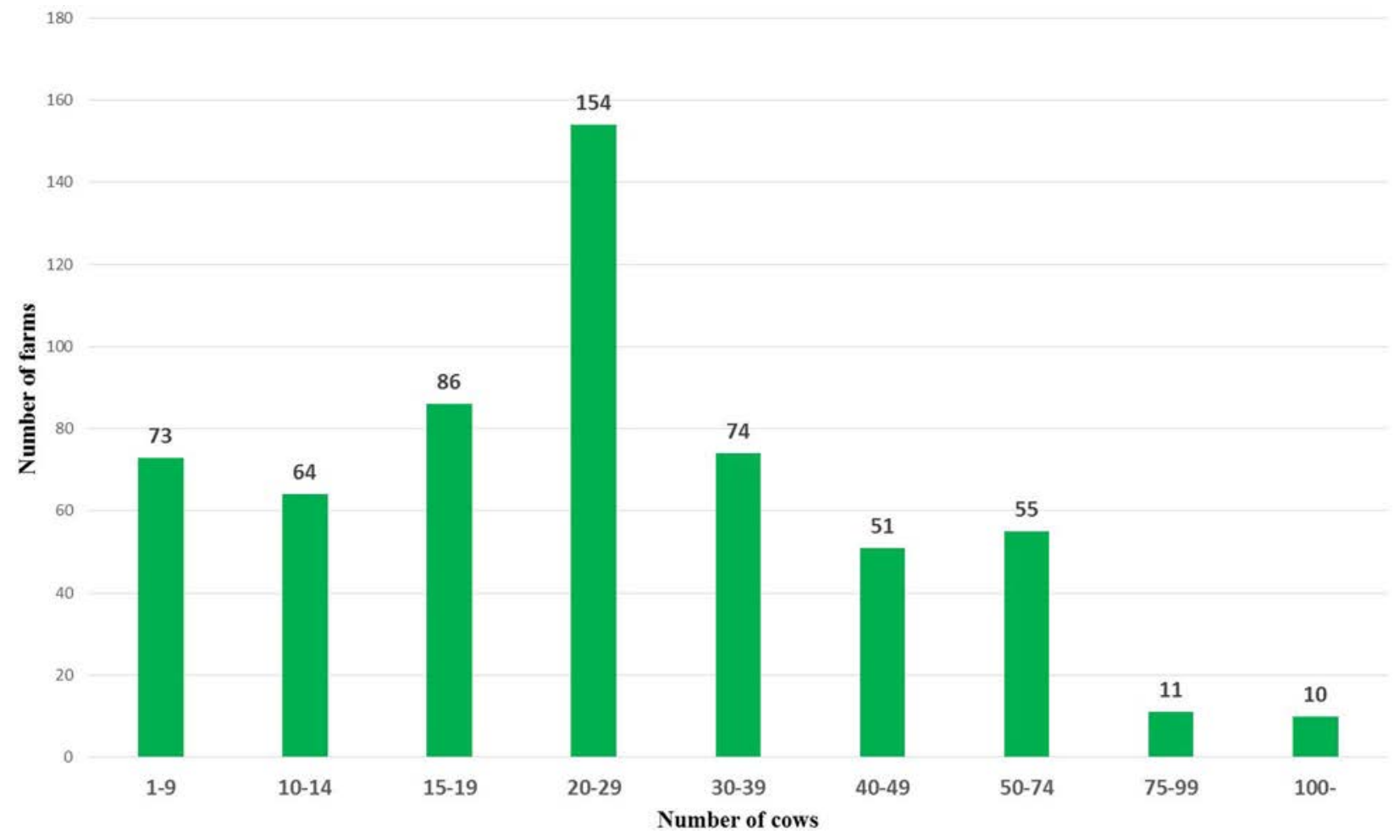

Fig. 2. Number of dairy cows per farm in North Karelia (2015).

Source: Pro Agria 2016.

present paper illustrates the above-mentioned overview of milk production in the region and offers preliminary results concerning farmers' challenges, adaptations and strategies drawn from the on-line survey and in part from the firststage interviews.

\section{Milk production in North Karelia}

North Karelia has been traditionally dominated by dairy farming since its fields are more suitable for forage production than arable cropping. Milk production is based on family-owned farms that are relatively small in area, but managed at high intensity. Most farms have between 20 and 29 cows (Fig. 2), which is a relatively small herd size compared with the ones in the most productive dairy regions of Europe.

In 2015, there were 554 milk farms in North Karelia. Out of the sixteen ELY Centres ${ }^{4}$, this

4 ELY Centre stands for the Centre for Economic Development, Transport and the Environment. Finland has 16 ELY Centres; their task is the promotion of regional competitiveness, well-being, sustainable development, and curbing climate change. Not all Centres have the same tasks; for instance, North Karelia, region ranks $5^{\text {th }}$ in the overall national milk production (Luke 2016). Although the number of dairy farms has sharply declined since the end of the 1980s (Fig. 3), as well as the overall number of cows (Fig. 4), milk production has remained fairly stable (Fig. 4); at the same time, the rise in the average milk production delivered to dairies per farm (Fig. 5), along with the average milk yield of cows which has doubled over the last 40 years, suggests that milk production is concentrated on ever fewer farms.

In North Karelia milk production is also important because it is the location of a Valio ${ }^{5}$ dairy factory, which processes 200 million litres of milk per year (North Karelian milk production was 136 million litres in 2014). In order to support dairy investments in the region, a deposit foundation has been established; municipalities, in particular the main urban centre of the region, Joensuu, strives for the processing plant to remain in the region. The establishment of the foundation is a sign of the commitment of the local governments to the development of

along with three other regions, is not responsible for transport duties.

5 Valio is Finland's largest milk processing company. 


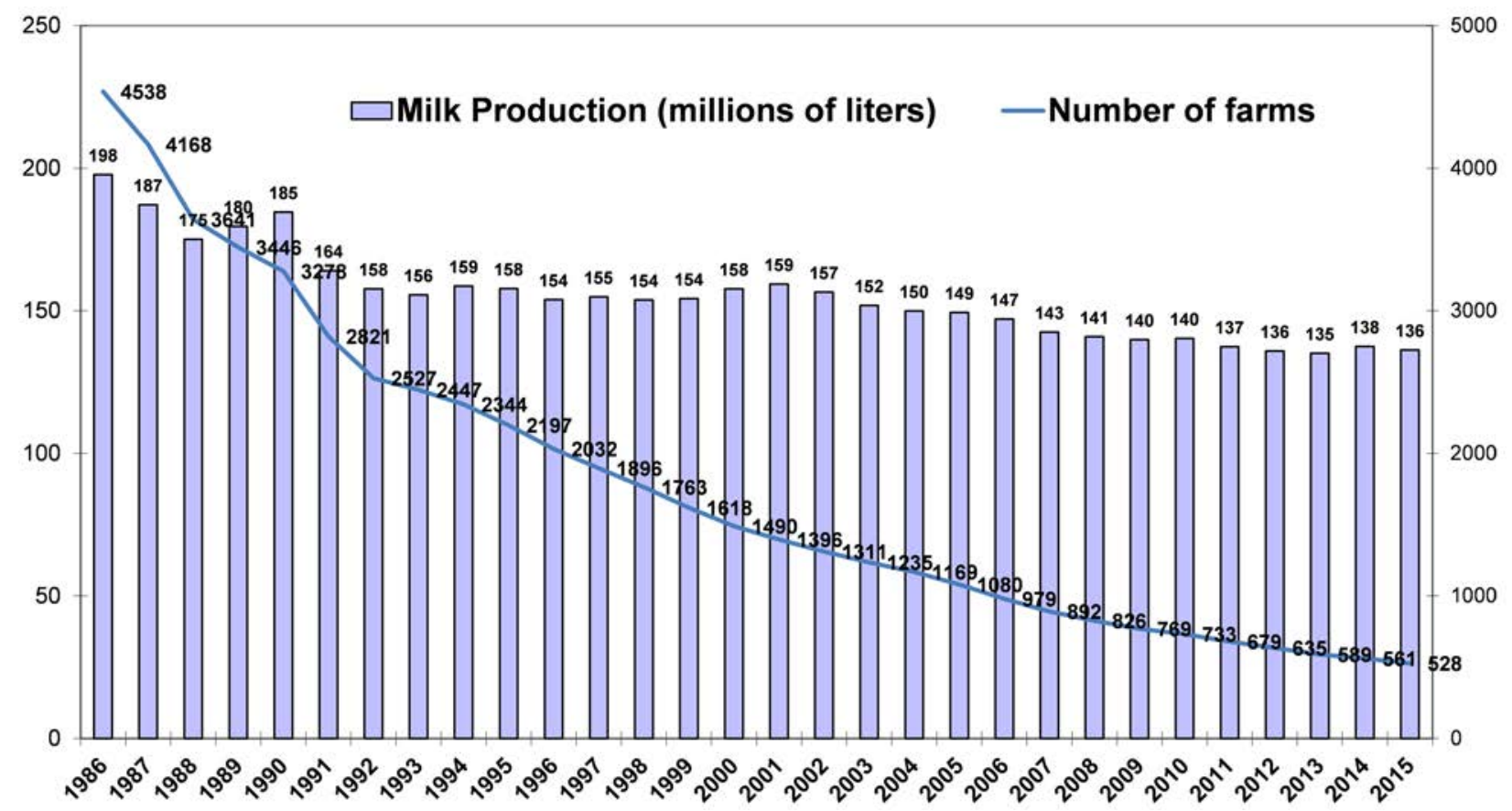

Fig. 3. Number of dairy farms and amount of milk production in North Karelia, 1986-2015. Source: Pro Agria 2016.

livelihoods in rural areas. The work of this foundation has just started; because of the milk crisis, it is very difficult to get funding from financial institutions. Many investments are paralysed. If a farm has a cash crisis, the bank does not give it a loan, and then the public sector cannot give the money. So far two decisions of the foundation have been positive, but in one case, although the foundation was guaranteeing, the bank has not given its share (information drawn from the

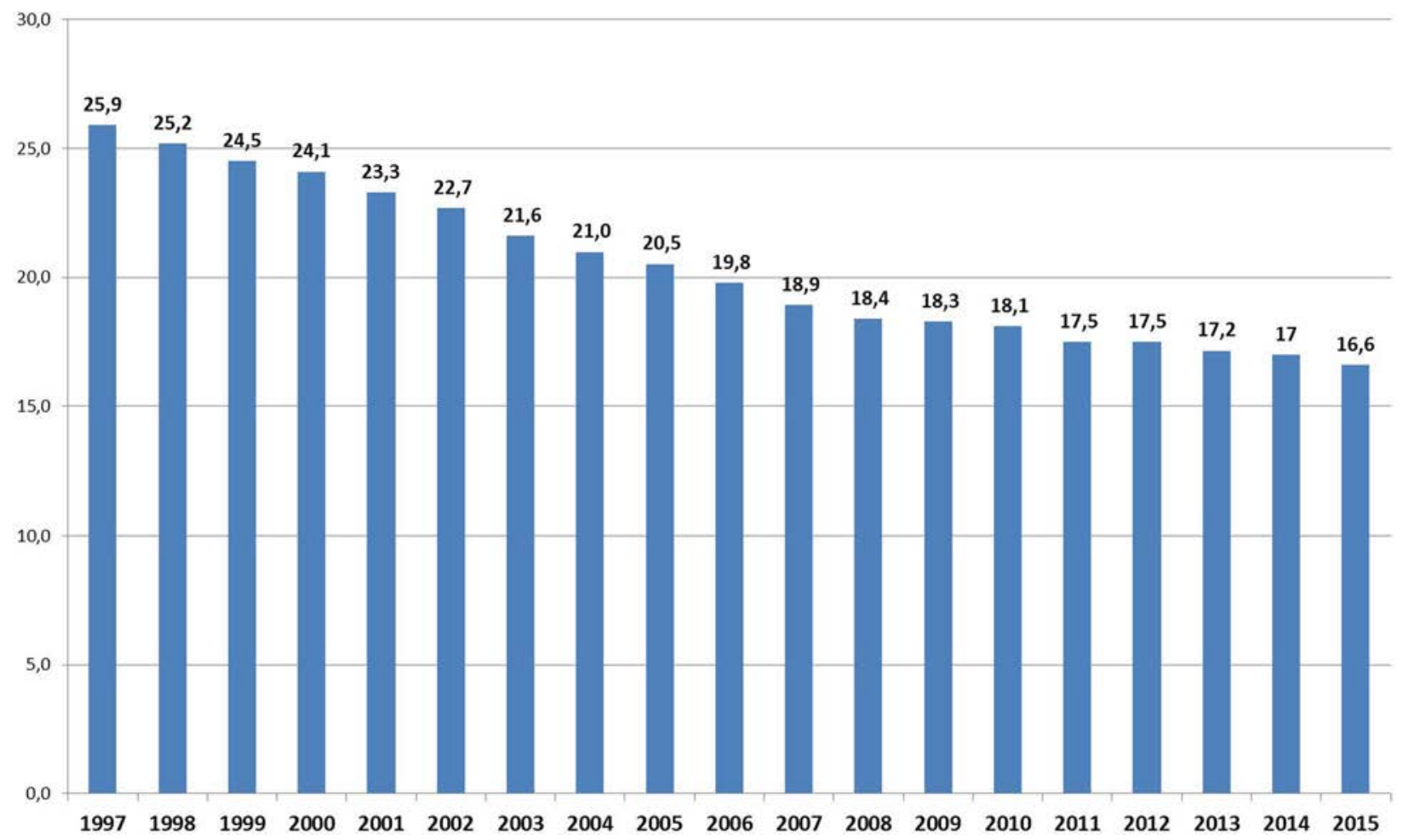

Fig. 4. Number of dairy cows in North Karelia, 1997-2015. Source: Pro Agria 2016. 


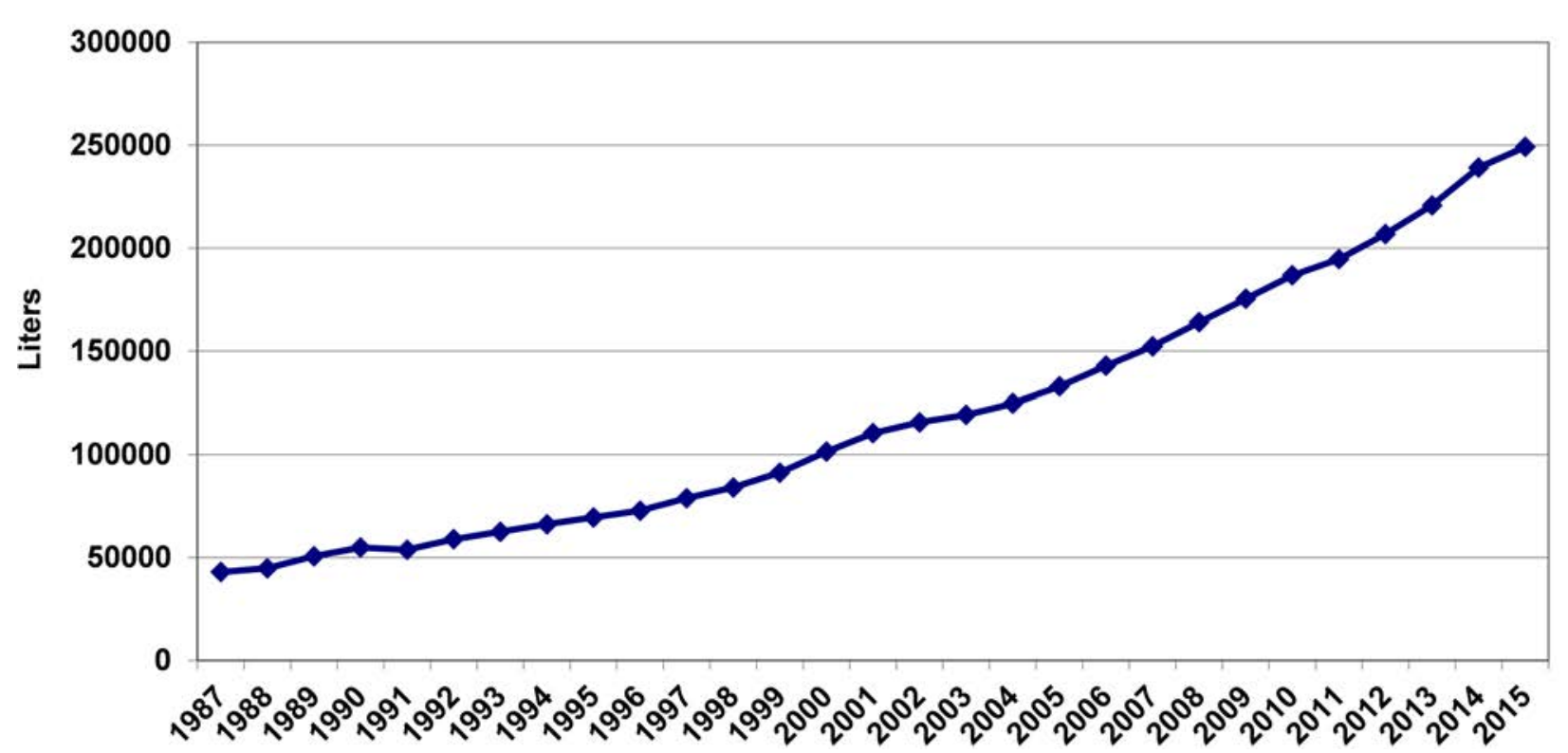

Fig. 5. Average amount of milk delivered to dairies per farm in North Karelia, 1987-2015. Source: Pro Agria 2016.

first-stage interviews). The reason may be the poor financial/ structural situation of the farm which requested the loan.

\section{The milk crisis: dairy farmers' challenges, strategies, and adaptations to change}

From the data collected there clearly emerges a milk crisis: there is more milk on the market than the actual demand for milk products. Dairy farmers' livelihood has been affected by the Russian import ban, by the abolition of milk quotas (especially in the long run), and to some extent by the limited number of supermarket chains in Finland. The price paid to the producers has gone down by 7-8 cents. As a consequence, the consumer price has also gone down. Farmers consider very carefully whether it is worth making investments; in the long term there is no sign that the price of milk might go up again. The dropping milk prices have affected both larger and smaller farms. However, larger farms are the ones which have made conspicuous investments, and therefore have big loans from the banks and are to a various degree 'forced' to stay in business to pay them off. Concerning the Finnish position on the abolition of dairy quotas, one of the milk sector experts from the first-stage interviews argued that: "the abolition of milk quotas has resulted in a fully liberal milk market. Finland has not supported such move [...]; this move has led to what we have always warned: the milk sector is in crisis because there is a lot of milk produced. At the moment there is no will to solve this situation, because the goal is to have a liberal milk market. In Finland we do believe that this fully liberal market does not fit this country; production needs regulation [...]. I believe that at some point in time milk production in Europe has to decrease, it has increased fast in the period 2010-2015. In Finland there is, however, a good balance between the milk produced and the milk consumed. We do believe without any doubt that Europe has dealt with this issue badly. The countries behind the abolition of milk quotas have been Denmark, Germany, the UK, Sweden, Holland, Belgium [...], all the best production countries including some eastern European countries like Poland, which wanted the abolition of milk quotas".

In the light of the abolition of milk quotas, one of the expected reactions from dairy farmers is that most of them would want to increase milk production on their farms; however, the data from the on-line survey suggest that dairy farmers in most cases have a cautious attitude to the new changes, and they are going to keep milk production the same as before (Fig. 6). To increase milk production would mean new investments 
In 2015 dairy quotas ended. In the light of the new system, are you thinking of:

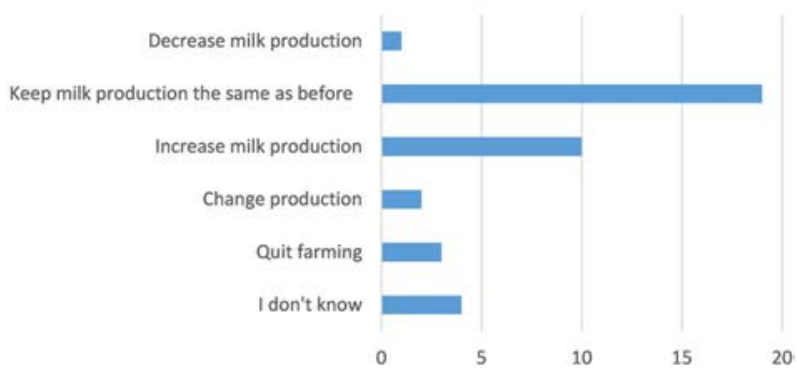

Fig. 6. Dairy farmers' plans in the light of the end of EU quotas.

(such as an increase in the herd and field size), and new loans from the bank.

The data, in fact, reveal that profitability is currently the biggest challenge in running a farm. In the on-line survey, at least a third of the respondents mentioned directly the word 'profitability', others referred to a variety of phenomena that in one way or another affect farms' profitability. For instance: (1) the low price paid to producers; (2) the poor financial situation; (3) the pressure to invest; (4) the rising costs, and (5) bureaucracy. Some challenges are not necessarily caused by material structures, but they are intrinsically linked to the profession of the dairy farmer. It is claimed that dairy farming is both very heavy work and a full-time activity conducted seven days per week. These factors can affect both the farmers' health (especially at older age), and the possibility of free time and social relations.

Flexibility and the ability to understand future trends are of key significance in adapting to socio-economic changes and unpredictability. Since in the future primary production will take environmental issues more and more into account, the construction of new barns, for instance, will have to consider animal welfare. Other important factors of the adaptation include the level of education, age, professional skills, motivation, willingness to take risks, and
Which of the following activities would have potential in your farm?

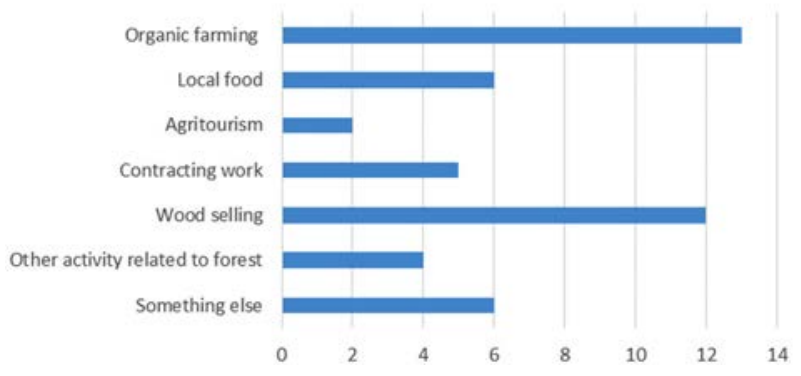

Fig. 7. Potential activities that farmers could undertake in their farming beyond basic production.

openness to new ideas. In the on-line survey, of the 31 respondents more than one third declared that organic farming had a potential on the farm (Fig. 7). "Production expansion does not seem an attractive alternative, so if I want to seek higher profitability, the transition to organic is a meaningful option" (a respondent from the online survey). Also wood selling and local food were deemed as having a good potential. One of the respondents claimed that "local food production is growing in popularity, and I support this kind of thinking. However, the production of local food would require a big investment and a lot of studying, so selling local food seems still far away, but is not a completely impossible idea". The potential economic activities listed by dairy farmers are rooted in the main strengths of the Finnish countryside: a clean environment, and the importance of forest on farms. These in turn, are key assets of a robust bio-economy in the future.

However, an adaptation to unpredictability would not be possible without the key characteristic of farming activity: agriculture is not only an income basis, but also a way of life, a sense of belonging to the land that significantly affects farmers' decision-making. Table 1 summarises the main dairy farmers' key challenges and adaptations to change.

Table 1. Farmers' key challenges and adaptations.

\begin{tabular}{|l|l|}
\hline \multicolumn{1}{|c|}{ Adaptations } & \multicolumn{1}{c|}{ Challenges } \\
\hline Innovativeness & Market turmoil and high volatility of the prices of products \\
\hline Healthy courage, not foolhardiness & High farms' debt \\
\hline Ability and willingness to cooperate & Farmers' inability to lead effectively and intelligently, with farms growing too fast \\
\hline Desire to learn new things & Jungle of EU regulations \\
\hline Agriculture as a way of life & Lack of continuity and certainty \\
\hline
\end{tabular}




\section{Final remarks}

At the core of many changes towards more sustainable agricultural systems is the farmer as an individual decision-maker. Decisions by each farmer, made in a complex world of contradictory interests and values, have an impact on sustainability. That is why it is important to have a better understanding on how decisions are made, both at the operational and the strategic level. This paper sheds some light on one of the most topical issues in European agriculture: structural changes affecting the dairy sector. The findings suggest that a milk crisis is in place, and farmers are under heavy pressure to cope with such changes. The most direct consequence of this crisis is the pressure to make investments. A key result shows how an adaptation to change is made by the combination of two interlinked factors: (1) agriculture seen as a way of life rather than as a profit-making endeavour, and (2) an ability to anticipate future changes in food production. At the same time, these elements are not enough for a sustainable agricultural system. An important issue would be to increase farmers' knowledge by linking them better with other actors of the countryside; it is especially important to increase mutual learning and develop new activities so that farmers are able to expand their own networks not only with other farmers, but also with other interest groups. The preliminary results discussed do not allow drawing generalisations about dairy farms in North Karelia, much less about farms in general. However, like Darnhofer (2010), they suggest that at least some farmers are engaged in the types of strategies that can be linked to resilience building. Thus, resilience thinking could be a helpful conceptual framework for understanding what strategies allow farmers to cope with shocks and take advantage of change, i.e. enhance their adaptive capacity.

\section{References}

Burton R.J.F., 2004. Seeing through the 'good farmer's' eyes: Towards developing an understanding of the social symbolic value of 'productivist behaviour'. Sociologia Ruralis 44(2): 195-215.

Darnhofer, I., 2010. Strategies of family farms to strengthen their resilience. Environmental Policy and Governance 20: 212-222.
Darnhofer I., Bellon S., Dedieu B., Milestad R., 2010. Adaptiveness to enhance the sustainability of farming systems. A review. Agronomy for sustainable development 30 (3): 545-555.

Darnhofer I., Lamine C., Strauss A., Navarrete M., 2016. The resilience of family farms: Towards a relational approach. Journal of Rural Studies 44: 111-122.

EU 2015. The end of the milk quotas. European commission, Agriculture and Rural Development. http://ec.europa.eu/ agriculture/milk-quota-end/index_en.htm (accessed 3 March 2017).

European Parliamentary Research Service 2015. The future of the EU dairy sector. http:// www.europarl.europa. eu/ RegData/ etudes/ BRIE/ 2015/569012/ EPRS_ BRI(2015)569012_EN.pdf.

Evans N., 2009. Adjustment strategies revisited: Agricultural change in the Welsh Marches. Journal of Rural Studies 25(2): 217-230.

Evans N., Morris C., Winter M., 2002. Conceptualizing agriculture: a critique of post-productivism as the new orthodoxy. Progress in Human Geography 26(3): 313-332.

Feola G., Binder C.R., 2010. Towards an improved understanding of farmers' behaviour: the integrative agent-centred (IAC) framework. Ecological Economics 69 (12): 2323-2333.

Frewer L.J., Fischer A.R.H., Wentholt M.T.A., Marvin H.J.P., Ooms B.W., Coles D., Rowe G., 2011. The use of Delphi methodology in agrifood policy development: some lessons learned. Technological Forecasting \& Social Change 78: 1514-1525.

Groeneveld A., Peerlings J., Bakker M., Heijman W., 2016. The effect of milk quota abolishment on farm intensity: shifts and stability. Wageningen Journal of Life Sciences 77: 25-37.

Huttunen S., Peltomaa J., 2016. Agri-environmental policies and 'good farming' in cultivation practices at Finnish farms. Journal of Rural Studies 44: 217-226.

Kings D., Ilbery B., 2010. The environmental belief systems of organic and conventional farmers: Evidence from central-southern England. Journal of Rural Studies 26 (4): 437-448.

Luke (Natural Resources Institute Finland), 2016. Alueittainen maidontutotanto. http:// stat.luke.fi/ tilasto/26.

Magnaghi A., 2010. Il progetto locale. Verso la coscienza di luogo. Bollati Boringhieri, Settimo Torinese.

McDonald R., Macken-Walsh A., Pierce K., and Horan B., 2014. Farmers in a deregulated dairy regime: insights from Ireland's new entrants scheme. Land Use Policy: 21-30.

Spencer J., Stewart N., 1973. The nature of agricultural systems. Annals of the Association of American Geographers 63(4): 529-544.

Van der Ploeg J.D., 1994. Styles of farming: an introductory note on the concepts and methodology. In: Van der Ploeg J.D., Long A. (eds), Born from within - practice and perspectives of endogenous rural development. Van Gorcum, Assen: 7-30.

Walker B., Holling C.S., Carpenter S.R., Kinzig A., 2004. Resilience, adaptability, and transformability in social-ecological systems. Ecology and Society 9(2): 5.

Yle, 2014. Lypsylehmien maidontuotanto tuplaantunut 40 vuoden aikana. http:// yle.fi/ uutiset/ 3-7404312

Zimmermann A., Heckelei T., 2010. Structural change of European dairy farms: A cross-regional analysis. Journal of Agricultural Economics 63(3): 576-603. 